\title{
Time-course of antigen-induced airway inflammation in the guinea-pig and its relationship to airway hyperresponsiveness
}

\author{
S. Underwood, M. Foster, D. Raeburn, S. Bottoms, J-A. Karlsson
}

Time-course of antigen-induced airway inflammation in the guinea-pig and its relationship to airway hyperresponsiveness. S. Underwood, M. Foster, D. Raeburn, S. Bottoms, J-A. Karlsson. CERS Journals Ltd 1995.

ABSTRACT: The causative relationship between airway inflammation and hyperreactivity is unclear, since inflammatory changes have been examined at one or, at most, a few time-points after antigen challenge in both human asthma and animal models. We have made a detailed investigation of inflammatory and functional changes in the airways up to 8 days after antigen challenge in guinea-pigs. In particular, we examined the hypothesis that eosinophil-derived mediators contribute to tissue damage and the development of airway hyperresponsiveness.

Following antigen challenge, the influx of inflammatory cells and mediator release in airway tissue and bronchoalveolar lavage fluid were correlated temporally with histopathological changes in airway tissue and airway responsiveness.

Eosinophil influx was demonstrable at $4 \mathrm{~h}$. Eosinophilia peaked after $24 \mathrm{~h}$ and persisted for at least 8 days. Parallel increases in the concentrations of major basic protein and eosinophil cationic protein in bronchoalveolar lavage fluid indicated that the eosinophils were activated. Eosinophilia was accompanied by subepithelial oedema and epithelial damage co-localized with major basic protein immunoreactivity. A transient neutrophilia $(<48 \mathrm{~h}$ duration) and an increase in neutrophil elastase in bronchoalveolar lavage fluid peaked at $14 \mathrm{~h}$. The proportion of airway macrophages with an activated morphology increased at $8 \mathrm{~h}$ and remained markedly elevated until $72 \mathrm{~h}$. Airways were hyperresponsive to histamine at $4 \mathrm{~h}$ and for at least 8 days.

The antigen-induced airway inflammation resemble in time-course and histopathology that seen in antigen-challenged asthmatics, and indicate that the eosinophil and its cytotoxic proteins may be major mediators of airway mucosal damage and airway hyperresponsiveness.

Eur Respir J., 1995, 8, 2104-2113.
Rhône-Poulenc Rorer Ltd, Dagenham Research Centre, Dagenham, Essex, UK.

Correspondence: J-A. Karlsson

Rhône-Poulenc Rorer Ltd

Dagenham Research Centre

Rainham Road South

Dagenham

Essex RM10 7XS

UK

Keywords: Airway hyperresponsiveness airway inflammation

asthma

eosinophils

guinea-pigs

Received: January 241995

Accepted after revision July 181995
Histological examination of bronchial biopsies and cytology of bronchoalveolar lavage fluid (BALE) have demonstrated infiltrating inflammatory cells in the tracheobronchial mucosa and airway lumen of patients with asthma, even those with mild disease $[1,2]$. The influx of inflammatory cells is accompanied by marked and characteristic pathophysiological changes to the airways [2], including thickening of the airway wall, which have been implicated in the restriction of airflow and the development of airway hyperresponsiveness. In some airways, the lumen may be further occluded by mucous plugs containing cellular debris. Epithelial desquamation limits the effectiveness of the mucociliary escalator and can expose underlying basal cells and sensory nerve endings. Damage to the airway epithelium may also result in the loss of epithelium-derived relaxant factors, important metabolic activity and a protective diffusion barrier [3].

Although biopsy and bronchoalveolar lavage (BAL) studies give valuable insights into tissue pathology, the correlation between changes in lung function and the appearance of cells and mediators is not always apparent. Consequently, the presence alone of a particular cell type or mediator at a single time-point does not confer a causal relationship with the occurrence of a late phase response or the degree of airway hyperresponsiveness. Previous studies in experimental animals have investigated cell infiltration at one or, at most, a few time-points after antigen challenge, and have attempted to correlate hanges with late phase responses or airway hyperresponsiveness [e.g. 4-6]. It is thus not surprising that highly contradictory results have been obtained as to whether or not inflammatory cell influx is associated with airway hyperresponsiveness $[$ e.g. 5, 7]. Furthermore, it is wellknown that cell type and number in BALF do not necessarily correlate with their presence in airway tissue.

The aims of the present investigation were to study inflammatory and functional changes in guinea-pig airways after antigen challenge and, especially, to examine the hypothesis that the eosinophil and its basic proteins 
mediate these events. The influx of inflammatory cells, mediator concentrations in BALF and histopathological changes in the airway wall were assessed at a range of time-points up to 8 days after challenge, and were correlated with the degree of airway hyperresponsiveness.

\section{Materials and methods}

\section{Animals}

Male, Dunkin Hartley guinea-pigs (300-350 g at time of sensitization; Charles River UK) were used throughout. UK Home Office guidelines for animal welfare based on the Animals (Scientific Procedures) Act 1986 were observed.

\section{Study design}

Sensitized guinea-pigs were challenged by exposure to antigen aerosol. At various time-points after challenge $(4,8,14,24,48,72,120$ and $192 \mathrm{~h})$, the cell populations and concentrations of elastase, major basic protein (MBP) and eosinophil cationic protein (ECP) in BALF were determined. Histopathological assessment of inflammatory changes and immunological demonstration of MBP reactivity were made in lung tissue from separate animals. In further animals, airway responsiveness to histamine was assessed. At each time-point, indices of inflammatory damage and airway responsiveness were compared with those in sensitized, unchallenged control animals. We have demonstrated that challenge with antigen vehicle (saline) has no effect on inflammatory parameters or airway responsiveness (data not shown).

\section{Sensitization and challenge protocols}

Animals were sensitized with ovalbumin (10 $\mu \mathrm{g})$ administered together with aluminium hydroxide $(100 \mathrm{mg})$ in saline ( $1 \mathrm{~mL}$ i.p.). Twenty one days later, successful sensitization was confirmed by the intradermal injection of ovalbumin $\left(25 \mu \mathrm{L}\right.$ of $\left.200 \mu \mathrm{g} \cdot \mathrm{mL}^{-1}\right)$ into the dorsal surface of the left pinna. Animals which did not respond with marked erythema and oedema (maximal after 20-40 min) were excluded from the study. Sensitized animals were used 8-15 days later for experiments.

Guinea-pigs were placed individually in a $3.5 \mathrm{~L}$ clear plastic chamber and challenged by $30 \mathrm{~s}$ exposure to an aerosol of ovalbumin $\left(2 \mathrm{mg} \cdot \mathrm{mL}^{-1}\right.$ in saline $)$ generated by a nebulizer (deVilbiss Pulmosonic). The aerosol was delivered into the chamber by an air pump $\left(300 \mathrm{~mL} \cdot \mathrm{min}^{-1}\right)$. At various time-points after challenge $(4,8,14,24,48,72$, 120 and $192 \mathrm{~h}$ ), airway inflammation and responsiveness were assessed.

\section{Assessment of airway inflammation}

Sensitized, challenged animals were killed with sodium pentobarhitone $\left(200 \mathrm{mg} \cdot \mathrm{kg}^{-1}\right.$ i.p. $)$. In addition, a group of sensitized, unchallenged animals was used as a control. The trachea was immediately cannulated and the airways lavaged with Roswell Park Memorial Institute (RPMI) 1640 medium at $22^{\circ} \mathrm{C}$ (two aliquots of $1 \mathrm{~mL} \cdot 100 \mathrm{~g}^{-1}$ body weight $(\mathrm{BW})$ ). To standardize the lavage technique, $60 \%$ of the instilled medium (the maximum that could be consistently recovered) was withdrawn from each animal. Total cell counts were performed using an automated cell counter (Coulter S-plus IV). Dilutions of lavage fluid (1 in 10) were made in RPMI 1640, and differential cell counts were made by light microscopy from Cytospin $₫$ preparations stained with modified Wright's stain (Hema-Tek®). At least 200 cells were counted on each slide. Cells were differentiated using standard morphological criteria. In addition to total macrophage numbers, the number of cells which showed the morphological characteristics (enlargement, vesicles and cytoplasmic projections) of activated airway macrophages in human asthmatics $[8,9]$ was determined. All differential cell counts were performed blind and in randomized order at the end of the study. Samples of undiluted lavage fluid were centrifuged (800 rpm, $10 \mathrm{~min}$ ) and the supernatant removed and stored at $-20^{\circ} \mathrm{C}$ until assayed for elastase, MBP and ECP.

MBP in lavage fluid was measured using an antigen capture enzyme-linked immunosorbent assay (ELISA) technique. Microtitre plates were coated with monoclonal antibodies for human MBP (BMK-13) at a concentration of $3 \mu \mathrm{g} \cdot \mathrm{mL}^{-1}$ in sodium carbonate $(15 \mathrm{mM}) /$ sodium bicarbonate $(35 \mathrm{mM})$ coating buffer $(\mathrm{pH} 9.5)$. After overnight incubation, the plates were washed twice with phosphate-buffered saline (PBS) containing Tween $20(0.05 \% \mathrm{v} / \mathrm{v})$. Remaining free binding sites were blocked by the addition of bovine serum albumin (BSA, 1\%) followed by a 60 min incubation at $20^{\circ} \mathrm{C}$. Following incubation, the plates were washed twice with PBS. Guinea-pig BALF $(100 \mu \mathrm{L})$ or human MBP $\left(0-800 \mu \mathrm{g} \cdot \mathrm{mL}^{-1}\right)$ were added to the plates in duplicate and incubated for $2 \mathrm{~h}$ at $20^{\circ} \mathrm{C}$. Plates were then washed three times with PBS-Tween 20. Detection antibody (alkaline phosphatase labelled immunoglobulin ( $\mathrm{IgG}$ ) diluted 1:400 in PBS) was added and the plates incubated for $90 \mathrm{~min}$ at $20^{\circ} \mathrm{C}$. Plates were then washed three times with PBS-Tween 20. The detection substrate (bromochloroindophenol) was added to the wells and the plates incubated for $60 \mathrm{~min}$ at $37^{\circ} \mathrm{C}$. Preliminary experiments demonstrated that the concentration of $\operatorname{MBP}\left(0-800 \mu \mathrm{g} \cdot \mathrm{mL}^{-1}\right)$ were linearly related to absorbance at $590 \mathrm{~nm}$. The limit of detection was $12 \mu \mathrm{g} \cdot \mathrm{mL}^{-1}$, with an intraanalytical variance of $<6 \%$. Using an immunoblotting assay, we have confirmed $>86 \%$ cross-reactivity between guinea-pig MBP and the BMK-13 antibody.

ECP in bronchoalveolar lavage fluid was measured by a similar antigen capture ELISA using polyclonal antibodies to human ECP derived from anti-ECP antisera raised in rabbits. Antibody was coated onto microtitre plates at a concentration of $5 \mu \mathrm{g} \cdot \mathrm{mL}^{-1}$. Standard human ECP was used as a calibrant in the range 0-3.2 $\mu \mathrm{g} \cdot \mathrm{mL}^{-1}$ and the alkaline phosphatase detection antibody was used at a 1:500 dilution. In all other respects, the assay was identical with that for MBP. The limit of detection was $25 \mathrm{ng} \cdot \mathrm{mL}^{-1}$, with an intra-analytical variance of $8 \%$. 
Table 1. - Histopathological scoring system used to assess inflammatory change in the lungs of antigen-challenged guinea-pigs

\begin{tabular}{llll}
\hline $\begin{array}{l}\text { Histopathology } \\
\text { grade }\end{array}$ & \multicolumn{1}{c}{$\begin{array}{c}\text { Perivascular and } \\
\text { peribronchiolar } \\
\text { eosinophilia }\end{array}$} & \multicolumn{1}{c}{ Oedema } & Epithelial damage \\
\hline 0 & $\begin{array}{l}\text { Normal } \\
\text { Low grade cell influx, } \\
\text { no tissue pathology } \\
\text { Low to moderate cell } \\
\text { influx, low grade tissue damage } \\
\text { Moderate cell influx, } \\
\text { low grade tissue damage } \\
\text { Moderate to high cell } \\
\text { influx, marked tissue damage } \\
\text { High cell influx, } \\
\text { significant tissue pathology }\end{array}$ & $\begin{array}{l}\text { Normal } \\
\text { Low grade diffuse } \\
\text { oedema } \\
\text { Moderate alveolar and } \\
\text { bronchiolar oedema } \\
\text { Regional and focal } \\
\text { oedema } \\
\text { Pronounced oedema }\end{array}$ & $\begin{array}{l}\text { Normal } \\
\text { Low grade cell loss }\end{array}$ \\
4 & & $\begin{array}{l}\text { Low grade cell loss } \\
\text { Pneumonic-type }\end{array}$ & Moderate cell loss \\
5 & & oedema & Moderate cell loss \\
& & & $\begin{array}{l}\text { Epithelial metaplasia, } \\
\text { mucus cell hyperplasia }\end{array}$ \\
\hline
\end{tabular}

Elastase in lavage fluid was measured fluorometrically using N-methoxysuccinyl-ala-ala-pro-val-1-amido4-methylcoumarin as substrate [10]. Because purified guinea-pig elastase is not currently available, elastase assay results could not be related to a calibration curve. Therefore, elastase concentrations are expressed as fluorescence $(\mathrm{F})$ units $\cdot \mathrm{mL}^{-1}$.

To avoid possible traumatic damage due to BAL, histopathological assessment of inflammatory changes in lung tissue were made in separate animals. The lungs were removed intact and then fixed by slowly inflating with buffered formalin $(5 \mathrm{~mL})$ and subsequently embedded in paraffin. Samples were removed from the middle, cranial, accessory and caudal lobes (16 samples in total for each animal). A transverse section (2-4 $\mu \mathrm{m}$ thick) was cut from each sample and stained with haematoxylin and eosin. Histopathological assessment (light microscopy) was performed blind on randomized sections. Inflammatory changes were graded using a semiquantitative scale of 0-5 (table 1) for perivascular eosinophilia, bronchiolar eosinophilia, epithelial damage and oedema. In addition, parallel sections were used for immunological demonstration of MBP reactivity using the BMK-13 antibody at a $1 / 300$ dilution in PBS. Visualization was via biotinylated secondary antibody with 3,3-diaminobenzidine as the demonstration chemistry.

\section{Measurement of airway responsiveness}

Airway hyperresponsiveness was assessed in separate animals. Animals were anaesthetized with sodium pentobarbitone $\left(60 \mathrm{mg} \cdot \mathrm{kg}^{-1}\right.$ i.p. $)$ and the trachea cannulated to allow mechanical ventilation with a respiration pump (Harvard 683 rodent ventilator) operating at 60 strokes $\cdot \mathrm{min}^{-1}$ with a stroke volume of $1 \mathrm{~mL} \cdot 100 \mathrm{~g}^{-1} \mathrm{BW}$. Pulmonary inflation pressure (PIP), a measurement of airway tone and lung impedence, was measured by a pressure transducer (Druck PDCR75) connected to a side arm from the tracheal cannula and was recorded on a pen recorder (Lectromed Multitrace 8). A cannula was placed in the left jugular vein to allow administration of histamine solutions. After allowing $20 \mathrm{~min}$ for the preparation to stabilize, increasing bolus doses of histamine $\left(1-50 \mu \mathrm{g} \cdot \mathrm{kg}^{-1}\right.$ i.v.) were administered at $6 \mathrm{~min}$ intervals and the resulting bronchoconstrictor responses recorded as increases in PIP. The dose of histamine causing an increase in PIP of $30 \mathrm{mmHg}$ (EDPIP30) was calculated by logarithmic regression.

\section{Materials}

The following materials and reagents were used: ovalbumin (grade V), histamine diphosphate, N-methoxysuccinyl-ala-ala-pro-val-7-amido-4-methylcoumarin, 3,3 diaminobenzidine, bovine serum albumin, bromochloroindophenol and Tween 20 (Sigma, UK); aluminium hydroxide, sodium carbonate and sodium bicarbonate (Rectapur grade, Prolabo, France); sodium pentobarbitone (Sagatal, Rhône Mérieux, UK); RPMI medium and PBS (Gibco, UK); modified Wright's stain (Hema-Tek, Miles Laboratories, UK); human ECP (Pharmacia Diagnostics UK); human MBP, BMK-13 antibody and biotinylated secondary antibody (Seralab, UK).

\section{Analysis of results}

Cell numbers and concentrations of mediators in BALF are expressed as mean \pm SEM for each time-point. Statistical significance of the differences between means was assessed using the Kruskal-Wallis multiple comparison test for nonparametric data, and a p-value of less than 0.05 was accepted as significant. Group size was eight animals for each time-point.

Because inflammatory changes assessed by histopathological examination were graded using asemiquantitative scale, data are presented as medians. Group size was three animals for each time-point.

For each time-point, histamine dose-response curves were constructed with each data point representing mean \pm sEM. Statistical significance of the differences between means was assessed using Student's one-tailed t-test for unpaired samples, and a p-value of less than 0.05 was accepted as significant. Histamine EDPIP30 
values are expressed as mean \pm SEM for each time-point. Statistical significance of the differences between means was assessed using one-way analysis of variance (ANOVA) and Dunnett's multiple comparison test for parametric data, and a p-value of less than 0.05 was accepted as significant. Group size was 5-12 animals for each timepoint.

\section{Results}

All guinea-pigs used in this study exhibited a marked reaction when challenged intradermally with antigen (ovalbumin), and developed acute dyspnoea when challenged with inhaled ovalbumin aerosol.
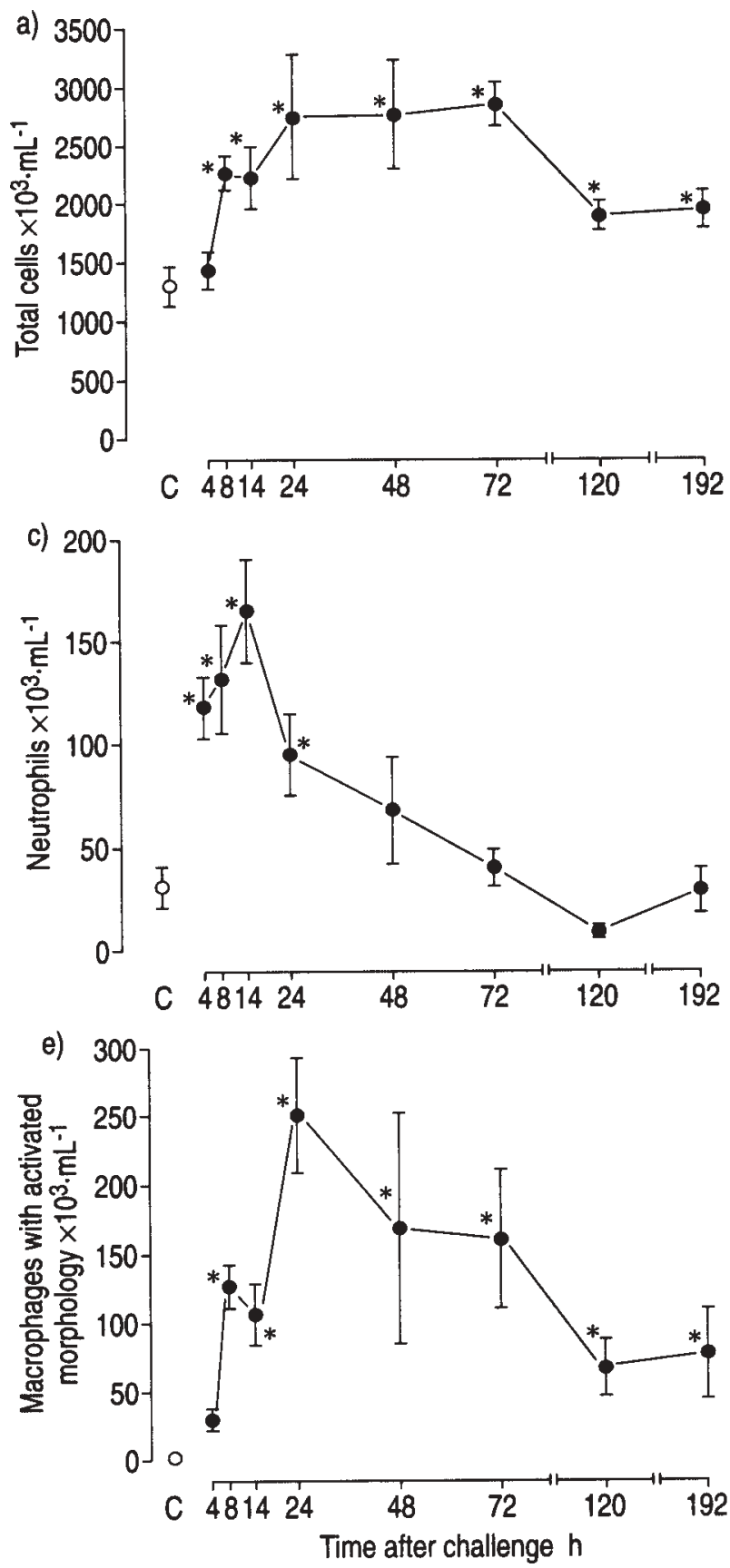

\section{Cells recovered by $B A L$}

Total cells. In sensitized, unchallenged guinea-pigs, the total number of cells recovered in BALF was $1,300 \pm 170$ $\times 10^{3}$ cells $\cdot \mathrm{mL}^{-1}(\mathrm{n}=8)$. The number was increased significantly $8 \mathrm{~h}$ after antigen challenge and reached a plateau between $24-72 \mathrm{~h}\left(2,740 \pm 540 \times 10^{3}\right.$ cells $\cdot \mathrm{mL}^{-1}$ after $24 \mathrm{~h}$; an increase of approximately $111 \%$ ). Numbers remained significantly elevated until at least $192 \mathrm{~h}$ after challenge (fig. 1a).

Eosinophils. The number of eosinophils recovered in BALF from sensitized, unchallenged guinea-pigs was $193 \pm 52 \times 10^{3}$ cells $\cdot \mathrm{mL}^{-1}(\mathrm{n}=8)$. The number was increased significantly $4 \mathrm{~h}$ after antigen challenge and reached a peak of $1,240 \pm 319 \times 10^{3}$ cells $\cdot \mathrm{mL}^{-1}$ after $24 \mathrm{~h}$ (an increase
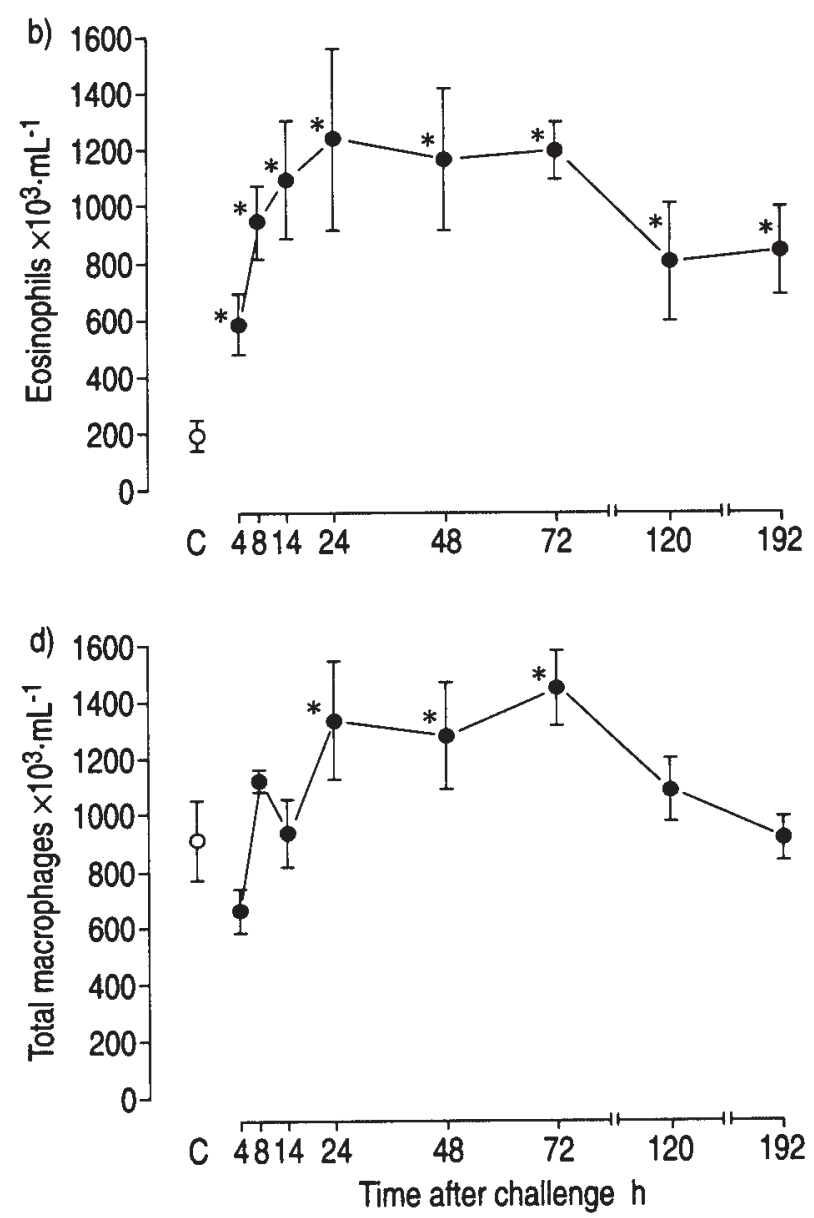

Fig. 1. - Time-course of the change in airway cell numbers recovered in bronchoalveolar lavage fluid after challenge with inhaled antigen (ovalbumin) in the sensitized guinea-pig. Results are presented as mean \pm SEM. $*$ : $\mathrm{p}<0.05$ compared with sensitized unchallenged $(\mathrm{C})$ animals. a) total cells; b) eosinophils; c) neutrophils; d) total macrophages; e) macrophages showing activated morphology. 
of approximately 542\%). Eosinophil numbers remained significantly elevated until at least $192 \mathrm{~h}$ after challenge (fig. 1b).

Neutrophils. In sensitized, unchallenged guinea-pigs, the number of neutrophils in BALF was $31 \pm 10 \times 10^{3}$ cells $\cdot \mathrm{mL}^{-1}(\mathrm{n}=8)$. Antigen challenge resulted in a transient neutrophilia. The number of cells was increased significantly at $4 \mathrm{~h}$ and reached a peak of $165 \pm 25$ $\times 10^{3}$ cells $\cdot \mathrm{mL}^{-1}$ after $14 \mathrm{~h}$ (an increase of approximately $432 \%$ ). In contrast to the persistent eosinophilia, neutrophil numbers declined until $48 \mathrm{~h}$ after challenge, when the population was no longer significantly different to that recovered from control animals (fig. 1c).

Monocytes/macrophages. The total number of monocytes/macrophages recovered in BALF from sensitized, unchallenged guinea-pigs was $912 \pm 141 \times 10^{3}$ cells $\cdot \mathrm{mL}^{-1}$ $(n=8)$. These cells showed no morphological signs of activation (see Methods). The total numbers of monocytes/macrophages recovered was significantly increased between 24 and $72 \mathrm{~h}$ after antigen challenge $(1,454 \pm 131$ $\times 10^{3}$ cells $\cdot \mathrm{mL}^{-1}$ after $72 \mathrm{~h}$; an increase of approximately $59 \%$ ) (fig. 1d). Activated macrophages were detected $8 \mathrm{~h}$ after antigen challenge. There was a marked and highly significant increase in the number of activated macrophages at all subsequent time-points, although maximum numbers were seen between 24 and $72 \mathrm{~h}$ after challenge $\left(251 \pm 42 \times 10^{3}\right.$ cells $\cdot \mathrm{mL}^{-1}$ after $\left.24 \mathrm{~h}\right)$ (fig. 1e). During this period, 11-19\% of monocytes/macrophages showed morphological signs of activation.

Lymphocytes. In sensitized, unchallenged guinea-pigs, the number of lymphocytes in BALF was $37 \pm 11 \times 10^{3}$ cells $\cdot \mathrm{mL}^{-1}$. There was no significant change in numbers recovered at any time-point after antigen challenge.

Desquamated epithelial cells were frequently observed in lavage fluid 24 and $48 \mathrm{~h}$ after challenge. Because these cells were often clumped, no attempt was made to count them.

\section{Eosinophil and neutrophil mediators in BALF}

ECP and MBP. The concentrations of ECP and MBP in cell-free lavage fluid increased after antigen challenge. The changes in ECP and MBP concentrations lagged behind but paralleled the lavage eosinophilia. The concentration of ECP was significantly increased $8 \mathrm{~h}$ after challenge and continued to rise to reach a plateau $24 \mathrm{~h}$ after challenge (fig. 2a). The concentration of ECP in lavage fluid was in the range $140-155 \mathrm{ng} \cdot \mathrm{mL}^{-1}$ from $24 \mathrm{~h}$ until $120 \mathrm{~h}$ after challenge (a maximum increase after $120 \mathrm{~h}$ of approximately $112 \%$ over basal). The concentration of MBP was significantly increased by $14 \mathrm{~h}$ after challenge, and also continued to rise until $24 \mathrm{~h}$ after challenge (fig. 2b) when the concentration reached $50 \pm 12 \mu \mathrm{g} \cdot \mathrm{mL}^{-1}$. The concentration remained significantly elevated (in the range $40-60 \mu \mathrm{g} \cdot \mathrm{mL}^{-1}$ ) for at least $192 \mathrm{~h}$. The maximum increase (after $120 \mathrm{~h}$ ) was approximately $161 \%$ over basal. Thus, the concentrations of both cytotoxic proteins increased after the onset of
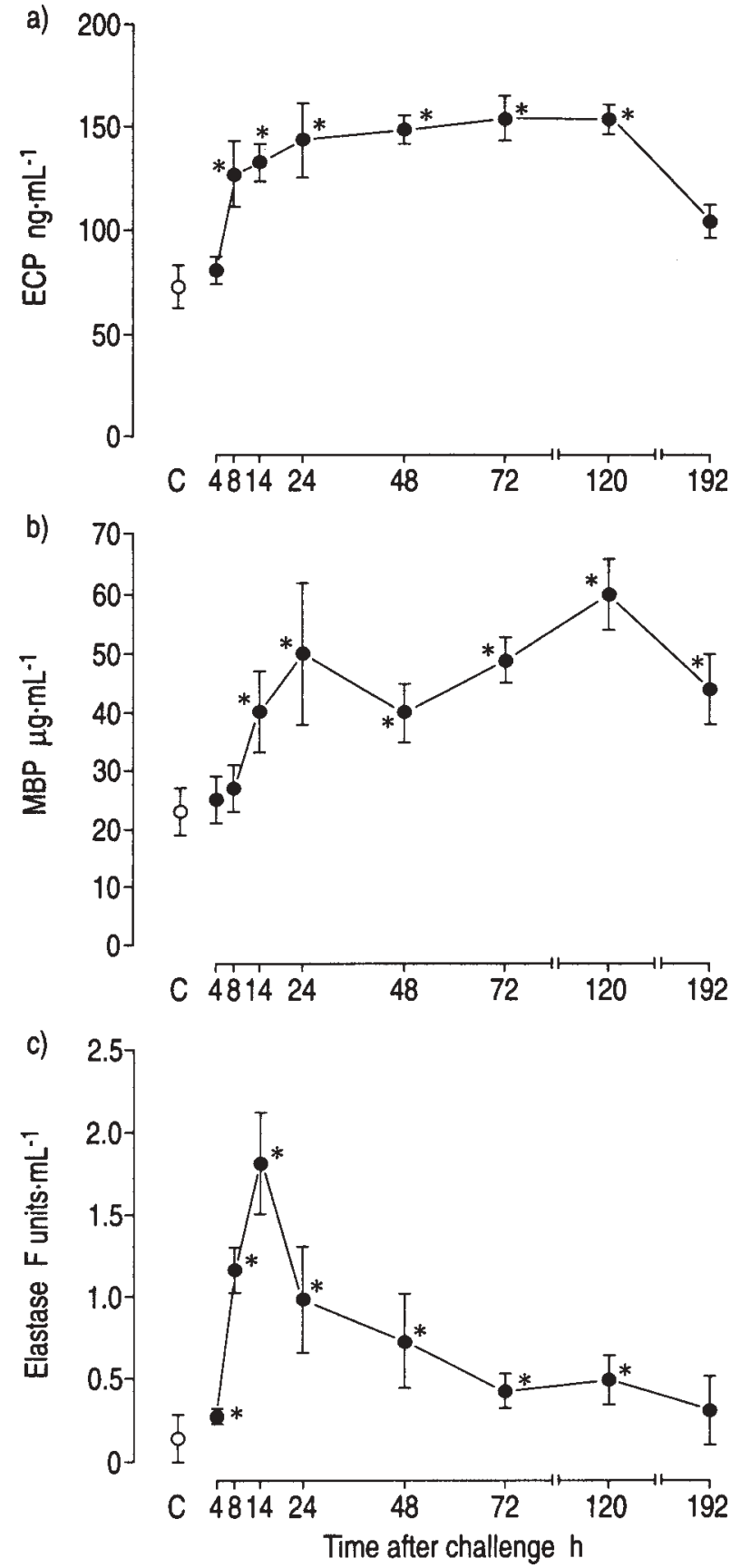

Fig. 2. - Time-course of the change in concentrations of markers of cell activity in bronchoalveolar lavage fluid after challenge with inhaled antigen (ovalbumin) in the sensitized guinea-pig. Results are presented as mean \pm SEM. *: $\mathrm{p}<0.05$ compared with sensitized unchallenged (C) animals. a) eosinophil cationic protein (ECP); b) major basic protein (MBP); c) elastase. F; fluorescence.

eosinophil influx. The concentration of MBP in lavage fluid was higher than that of ECP.

Neutrophil elastase. The concentration of elastase in lavage fluid increased after antigen challenge. There was a small but significant increase $4 \mathrm{~h}$ after challenge and the concentration continued to rise to reach a peak $14 \mathrm{~h}$ after challenge. The concentration remained significantly elevated until at least $120 \mathrm{~h}$ after challenge (fig. 2c). 
Table 2. - Time-course of inflammatory changes in lung sections after challenge with inhaled antigen (ovalbumin) in the sensitized guinea-pig

\begin{tabular}{rcccc}
\hline $\begin{array}{c}\text { Time after } \\
\text { challenge } h\end{array}$ & $\begin{array}{c}\text { Perivascular } \\
\text { eosinophilia }\end{array}$ & $\begin{array}{c}\text { Peribronchiolar } \\
\text { eosinophilia }\end{array}$ & Oedema & $\begin{array}{c}\text { Epithelial } \\
\text { damage }\end{array}$ \\
\hline Control & $1(1-2)$ & $0(0-1)$ & $1(1-1)$ & $0(0-0)$ \\
4 & $2(1-2)$ & $1(0-1)$ & $1(1-1)$ & $0(0-1)$ \\
8 & $4(4-5)$ & $4(3-5)$ & $2(2-2)$ & $2(1-3)$ \\
14 & $3(2-3)$ & $4(3-5)$ & $4(4-5)$ & $4(3-5)$ \\
24 & $4(3-5)$ & $5(5-5)$ & $3(3-4)$ & $5(4-5)$ \\
48 & $3(2-3)$ & $5(5-5)$ & $3(4-5)$ & $5(5-5)$ \\
72 & $1(1-2)$ & $5(5-5)$ & $1(1-2)$ & $5(4-5)$ \\
120 & $2(1-3)$ & $3(2-4)$ & $1(1-2)$ & $4(3-5)$ \\
192 & $1(1-1)$ & $3(2-3)$ & $4(3-5)$ &
\end{tabular}

Inflammatory changes were graded by histopathological assessment using a semiquantitative scale of 0-5 (table 1). Results are presented as median, with range in parenthesis. Group size was 3 for each time-point. C: control, sensitized unchallenged animals.

\section{Lung histology}

Histopathological examination of sensitized, unchallenged control animals revealed no significant abnormalities. There was a low grade eosinophilia in some sections, but this was not associated with pathological changes.

In sensitized, challenged animals, there was an initial perivascular eosinophilia, giving way to an elevated peribronchiolar eosinophilia $8 \mathrm{~h}$ after challenge (table 2 ). This suggests a net movement of these cells from the vascular to the bronchiolar compartment. The bronchiolar eosinophil influx peaked 24-72 h after challenge (table 2) and did not show complete resolution by $192 \mathrm{~h}$. The presence of eosinophils in the bronchiolar area showed anatomical correlation with tissue oedema (table 2), epithelial cell hypertrophy and damage (table 2) and airway lumen plugging by mucus and cells, and focal loss of integrity of the smooth muscle layer (figs 3 and 4). Specific alveolitis was not observed. In contrast to the marked eosinophilia, a very low grade neutrophil infiltration of lung tissue was observed 4-72 $\mathrm{h}$ after challenge.

In sensitized, challenged animals, immunohistological analysis of MBP showed enhanced deposition in the bronchiolar area which correlated anatomically with sites of eosinophil localization. Damage to the subepithelial mucosa, oedema, damage to the smooth muscle layer and epithelial cell pathology correlated with sites of MBP reactivity and intrusion of eosinophils into the tissue. The frequent co-localization of free MBP immunostaining with sites of tissue pathology suggests that the damage arises as a consequence of the exocytosis of eosinophil granule contents (figs 3 and 4). MBP immunoreactivity was not observed in sensitized, unchallenged control animals.

\section{Airway hyperresponsiveness}

Histamine (bolus i.v.) caused a dose-related bronchoconstriction in anaesthetized guinea-pigs. The histamine EDPIP30 in sensitized, unchallenged guinea-pigs was $11.3 \pm 1.5 \mu \mathrm{g} \cdot \mathrm{kg}^{-1}$. Four hours after antigen challenge, the EDPIP30 had fallen significantly to $3.7 \pm 0.6 \mu \mathrm{g} \cdot \mathrm{kg}^{-1}$.

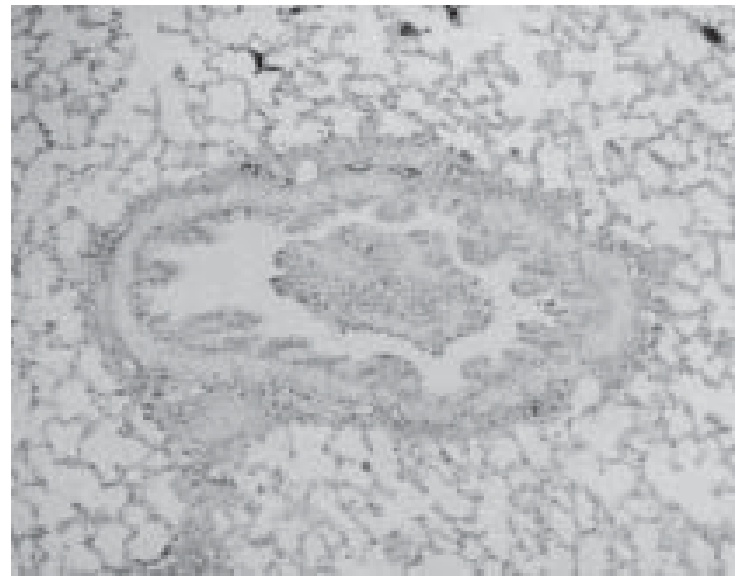

Fig. 3. - Bronchiolar region showing pronounced major basic protein (MBP) immunoreactivity in the mucosa $24 \mathrm{~h}$ after antigen challenge. The lumen contains a mucous/cell plug. (Haematoxylin and eosin BMK-13; magnification $\times 60$ )

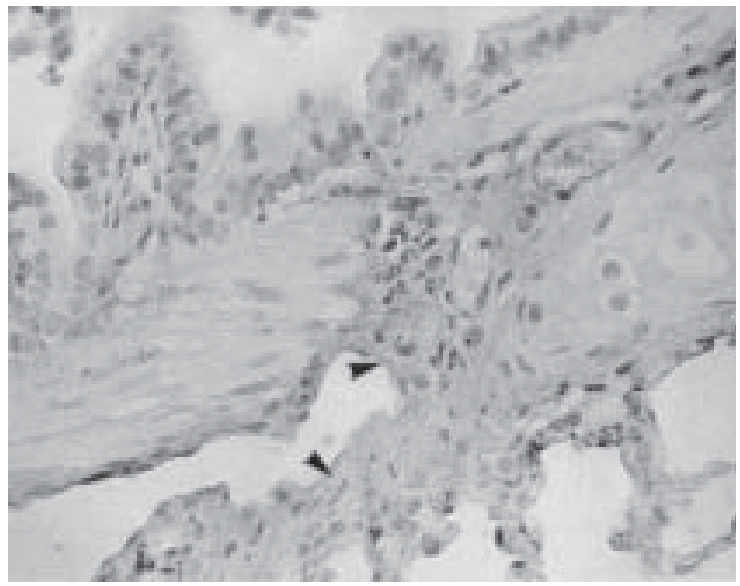

Fig. 4. - Section through bronchiolar region showing extensive damage to bronchiolar smooth muscle and mucosa co-localized with major basic protein (MBP) (arrows) $120 \mathrm{~h}$ after antigen challenge. (Haematoxylin and eosin BMK-13; magnification $\times 200$ ).

There was a parallel shift to the left of the dose-response curve demonstrating that the airways had become hyperreactive (fig. 5). Although the minimum EDPIP30 (greatest responsiveness) was achieved $4 \mathrm{~h}$ after challenge, the 


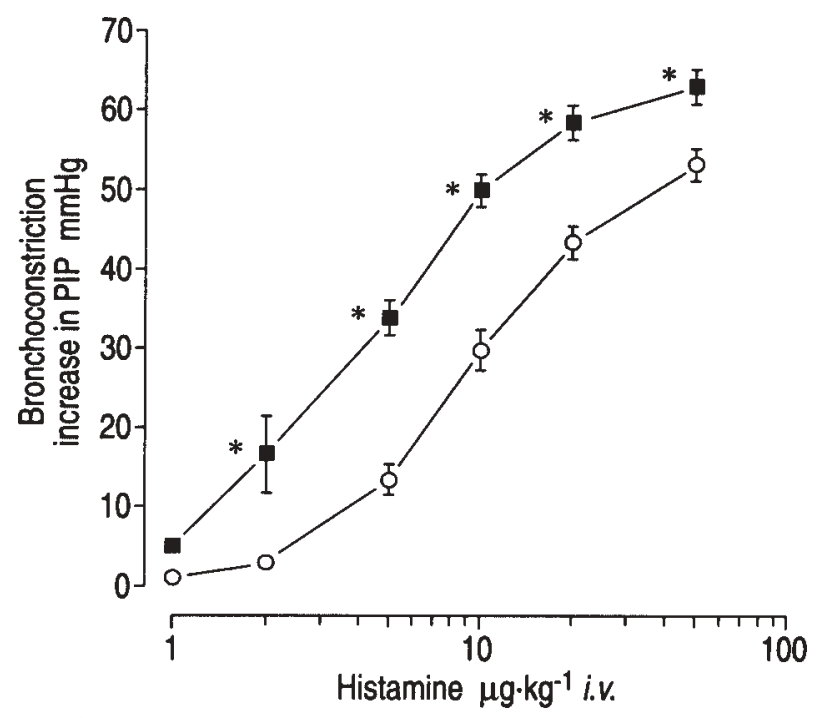

Fig. 5. - Dose-response curves to histamine (bolus i.v.) in the sensitized guinea-pig. ( - —) unchallenged; and (- - $4 \mathrm{~h}$ after challenge with inhaled antigen (ovalbumin). Results are presented as mean \pm SEM. *: $\mathrm{p}<0.05$ compared with unchallenged animals. PIP: pulmonary inflation pressure.

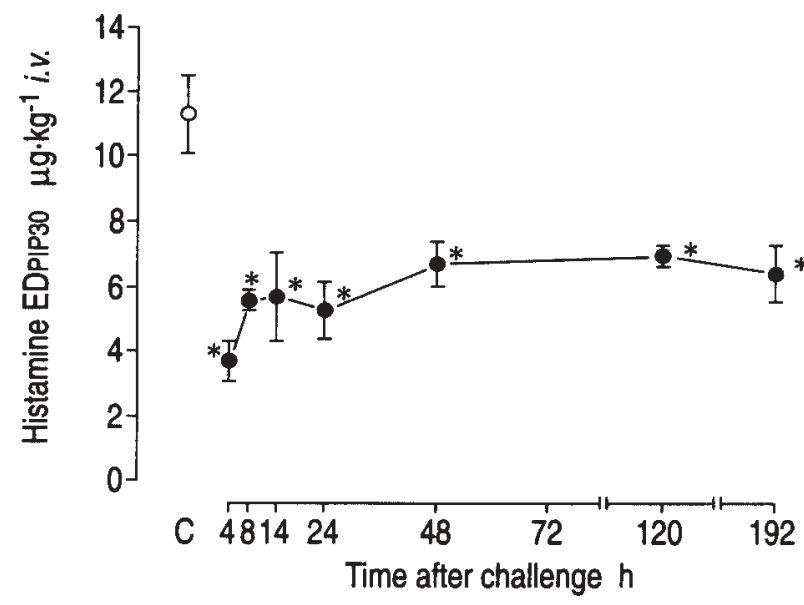

Fig. 6. - Time-course of the change in bronchial reactivity assessed as the bolus intravenous dose of histamine causing an increase in pulmonary inflation pressure of $30 \mathrm{mmHg}$ (EDPIP30) following challenge with inhaled antigen (ovalbumin) in the sensitized guinea-pig. Results are presented as mean \pm SEM. *: $\mathrm{p}<0.05$ compared with unchallenged (C) animals (time 0 ).

airways remained significantly hyperreactive until at least $192 \mathrm{~h}$ after challenge (fig. 6).

\section{Discussion}

In the present study, we have examined the time-course of antigen-induced inflammatory changes produced in guinea-pig BALF and lung tissue. A prominent feature of the antigen-induced airway inflammation was an eosinophilia persisting for at least 8 days after a single challenge with antigen. Perivascular eosinophilia, suggesting recruitment of eosinophils from the vasculature, was observed in lung tissue at the earliest time-point studied ( $4 \mathrm{~h}$ after challenge) and progressed during the next $4 \mathrm{~h}$ to eosinophilia around the bronchi and bronchioles.
This finding is in agreement with that of DuNN et al. [11], who noted eosinophil margination in the bronchial vasculature $8 \mathrm{~min}$ after antigen challenge, which developed into a peribronchiolar eosinophilia at $6 \mathrm{~h}$. In our study, the numbers of eosinophils infiltrating the perivascular tissue declined $48 \mathrm{~h}$ after challenge, indicating that recruitment was falling by this time. However, the bronchiolar and lavage fluid eosinophilia were maintained over a prolonged period of time (at least 8 days). The life span of these cells in tissue may be up to 5 days [12] but is probably enhanced by cytokines, such as interleukin-5 (IL-5) and granulocyte/macrophage colony-stimulating factor (GM-CSF) [13], produced in increased amounts in inflamed tissue. Our finding confirms those of other workers who have demonstrated a prolonged (at least 7 days) increase in the number of eosinophils in BALF [5, 11, 14] and in lung tissue [11] after antigen challenge in the guinea-pig.

Activated eosinophils secrete a range of granule-derived cytotoxic proteins, including ECP and MBP, both of which have been shown to damage airway cells, especially those of the epithelium. In our study, ECP and MBP concentrations in lavage fluid increased in parallel to, but lagged slightly behind, the increase in eosinophil numbers. The concentration of ECP appeared to increase before that of MBP, a finding which is consistent with the location of MBP in the core of the eosin-staining granules and ECP in the matrix [15]. Interestingly, the concentrations of these cytotoxic proteins remained elevated for at least 8 days, indicating that the eosinophils continued to be activated. An intriguing observation in this study was the localization of eosinophils and MBP immunoreactivity to areas of tissue damage. Based on the proinflammatory and cytotoxic effects of eosinophilderived proteins, it seems likely that ECP and MBP were major contributors to the tissue oedema and epithelial cell hypertrophy and sloughing seen in this study.

When comparing the cytotoxic activities of MBP and ECP in vitro, FRIGAs et al. [16] found that guineapig-derived MBP $\left(50-100 \mu \mathrm{g} \cdot \mathrm{mL}^{-1}\right)$ was sufficient to cause extensive injury to guinea-pig epithelial cells after $12 \mathrm{~h}$ incubation. Furthermore, morphologically this injury resembled the damage to bronchial epithelium seen in patients with asthma. ECP was reportedly less cytotoxic, a concentration of $100 \mu \mathrm{g} \cdot \mathrm{mL}^{-1}$ causing less pronounced injury. In the present study, we have determined the concentrations of MBP and ECP recovered in an instilled volume of BALF and have demonstrated that the concentration of MBP in contact with the epithelium following antigen challenge could be at least as high as that previously shown to cause damage to these cells. Whether the concentration of ECP observed is also sufficient to cause injury is less clear. Since the concentrations in interstitial fluid, at the sites of eosinophil accumulation close to epithelial cells, would be predicted to be even higher, further support for a role for MBP and ECP is provided.

It is now well-established that there are increased eosinophil numbers in the airways of patients with ongoing asthma, even those with mild disease [17], whilst autopsy and biopsy studies have revealed a 
characteristic eosinophil infiltration of the airway mucosa [1]. Antigen challenge results in a further increase in the number of eosinophils in BALF as early as $4 \mathrm{~h}$ later [1820]. Eosinophil numbers remain elevated for at least $96 \mathrm{~h}$ [8]. Accumulating evidence suggests that epithelial cell damage and shedding are important features of asthma [1]. Bronchial biopsy specimens have revealed areas of epithelial destruction and evidence of oedematous fluid at the base of the epithelium in less damaged areas [21]. In asthma patients, levels of ECP and MBP in BALF are elevated, and there appears to be a correlation between the concentrations of these proteins, the numbers of desquamated epithelial cells recovered in lavage fluid and airway hyperresponsiveness [22-25]. MBP has been found deposited within damaged areas of the bronchial wall in patients who die of asthma [26]. Thus, eosinophil migration, accumulation and degranulation in the guineapig lung mimics that reported in the human asthmatic lung. By investigating the time-course of these events, we have provided a strong argument for the role of this cell in tissue damage and hyperresponsiveness (see below).

Airway hyperresponsiveness persisted for at least 8 days after antigen challenge, suggesting that it was supported by the inflammatory pathology. However, the onset of hyperresponsiveness occurred within $4 \mathrm{~h}$ of challenge, before the development of marked inflammatory changes. This suggests that acute changes in smooth muscle function induced by mediators released from resident or earlier recruited cells could play a role in the early onset of hyperresponsiveness in this model. Antigeninduced airway hyperresponsiveness in the guinea-pig is inhibited by a thromboxane synthetase inhibitor (CS-518), suggesting that release of endogenous thromboxane $\mathrm{A}_{2}\left(\mathrm{TXA}_{2}\right)$ may contribute to the increased responsiveness [27]. Indeed, $\mathrm{TXA}_{2}$ has been found to be the predominant eicosanoid released by antigen challenge from isolated, perfused guinea-pig lungs [28]. Platelet-activating factor (PAF), a product of several inflammatory cell types, including airway macrophages and eosinophils, could contribute since it has been shown to induce acute airway hyperresponsiveness in the guineapig [29]. Interestingly, PAF-induced hyperresponsiveness in the guinea-pig is inhibited by a thromboxane synthetase inhibitor (OKY-046), suggesting that it may act by increasing the endogenous release of $\mathrm{TXA}_{2}$ [30]. PAF increases $\mathrm{TXA}_{2}$ release from guinea-pig eosinophils implicating these cells as one potential source of this lipid [31]. As in human asthma, leukotrienes are also implicated in the induction of antigen-induced airway hyperresponsiveness in the guinea-pig. A leukotriene synthesis inhibitor (MK-886) has been shown to prevent antigeninduced hyperresponsiveness in this species, whilst leukotriene $\mathrm{C}_{4}\left(\mathrm{LTC}_{4}\right)$ has been shown to cause hyperresponsiveness to acetylcholine [32]. MBP increases the responsiveness of intact, but not epithelium denuded, guinea-pig trachealis in vitro [33], suggesting that it may cause immediate hyperresponsiveness by inducing the secretion of an as yet unidentified bronchoconstricting agent from the epithelium, or by making submucosal tissue more accessible to inhaled mediators. Although $\mathrm{ECP}$ and MBP concentrations in BALF had not risen significantly until much later after antigen challenge, it cannot be excluded that these cationic proteins, together with other mediators, contributed to early local changes in the bronchial wall.

In our study, there was a transient $(<48 \mathrm{~h})$ neutrophilia in the guinea-pig airways after antigen challenge. The rate at which neutrophil numbers declined is consistent with the 1-2 day life span of these cells in tissue [34]. The transient nature of neutrophil accumulation in the guinea-pig lung following antigen challenge has been a consistent finding in other studies [11, 35-37]. The concentration of neutrophil-derived elastase in BALF increased in parallel with the neutrophilia. However, the concentration remained significantly elevated, although well below its peak, until at least $120 \mathrm{~h}$ after challenge, despite the short life span of tissue neutrophils and the fact that neutrophilia had resolved by this time. This suggests that the small number of neutrophils remaining were still activated or that elastase has a long half-life in tissue, perhaps remaining associated with tissue glycoproteins or mucus.

In asthmatics, neutrophil numbers have been reported to increase in bronchial lavage fluid $4 \mathrm{~h}$ after antigen provocation $[8,19]$, but neutrophilia is generally of shorter duration than eosinophilia [8, 18, 38]. Studies provide no consistent evidence for a maintained increase in the numbers or activity of neutrophils in the airways of asthma patients, suggesting that these cells may be less implicated in the chronic inflammatory changes than eosinophils and their products.

The predominant cells in BALF recovered from unchallenged guinea-pigs were those of the monocyte/ macrophage lineage. The numbers of these cells were increased after challenge confirming the findings of TARAYRE et al. [39]. In contrast, other workers have not found an increased monocyte influx [35, 37, 40]. Thus, unlike eosinophils and neutrophils, monocyte recruitment is not a consistent feature of the airway inflammatory response following antigen challenge in this species. However, we have demonstrated for the first time that after antigen challenge there is an increase in the proportion of macrophages displaying an activated morphology. Interestingly, the proportion of cells with the activated morphology increased from less than $1 \%$ in unchallenged animals to $19 \%$, representing a very significant change. The macrophage has the capacity to secrete a wide range of cytokines, chemotactic agents, enzymes and other mediators, and may well have contributed both to the early and sustained changes in airway cell numbers and to airway hyperreactivity.

Under most conditions, cells of the monocyte/macrophage lineage are the most numerous type in normal and asthmatic human airways. Thus, the prevalence of these cells in the guinea-pig's airways reflects the situation in human airways. In stable asthmatics, macrophage numbers in bronchial lavage fluid are increased 48 and $96 \mathrm{~h}$ after antigen provocation [8]. Bronchial biopsy studies have shown increased numbers of macrophages in the airway mucosa of patients with ongoing asthma [41], while the numbers recovered in BALF is not increased [9]. However, a higher proportion of the macrophages 
recovered from asthmatic patients were hypodense and exhibited an activated morphology [9].

In common with other workers [35, 37, 40], we saw no significant change in the number of lymphocytes recovered by BAL from guinea-pig airways after antigen challenge. However, FREw et al. [42] used immunocytochemical techniques to demonstrate a rise in $\mathrm{T}$ lymphocyte numbers in the airway wall after challenge. This influx was not reflected by an increase in the numbers of T-cells in BALF, suggesting that these cells infiltrate the mucosa but may not migrate to the airway lumen in this species. In contrast, LAPAE SILVA et al. [43] used a panel of monoclonal antibodies but failed to demonstrate an influx of T-cells into the airway wall after challenge. Although an influx of lymphocytes does not appear to be a consistent feature of airway inflammation in this model, it remains possible that antigenspecific T-lymphocytes resident in the airway wall become activated as a result of antigen challenge. Thus, T-cells may, by secreting interleukin-4 (IL-4), IL-5 and other proinflammatory cytokines, contribute to the orchestration of the ensuing allergic reaction.

In conclusion, the results of this study demonstrate that, in guinea-pig airways, antigen challenge induced eosinophil infiltration and activation (ECP/MBP release) similar to that reported in human asthmatics. The eosinophilia and MBP immunoreactivity were temporally and spatially associated with damage to the airway mucosa and airway hyperresponsiveness. Changes in the numbers of other cell types (neutrophils, macrophages and lymphocytes) did not correlate directly with structural hanges or functional effects. We conclude that eosinophil products may be the major mediators of damage to the airway mucosa and enhancement of airway hyperresponsiveness in antigen challenged guinea-pigs.

Acknowledgements: The authors wish to thank V. Woodman and D. Noble for valuable assistance.

\section{References}

1. Djukanovic R, Roche WR, Wilson JW, et al. Mucosal inflammation in asthma. Am Rev Respir Dis 1990; 142: 434-457.

2. Beasley R, Burgess C, Crane J, Pearce N, Roche W. Pathology of asthma and its clinical implications. $J$ Allergy Clin Immunol 1993; 92: 148-154.

3. Raeburn D. Eicosanoids, epithelium and airway hyperreactivity. Gen Pharmacol 1990; 21: 11-16.

4. Gundel RH, Gerritsen ME, Gleich GJ, Wegner CD. Repeated antigen inhalation results in a prolonged airway eosinophilia and airway hyperresponsiveness in primates. J Appl Physiol 1990; 68: 779-786.

5. Sanjar S, Aoki S, Kristersson A, Smith D, Morley J. Antigen challenge induces pulmonary airway eosinophil accumulation and airway hyperreactivity in sensitized guinea-pigs: the effect of anti-asthma drugs. Br J Pharmacol 1990; 99: 679-686.

6. Pretolani M, Ruffie C, Joseph D, et al. Role of eosinophil activation in the bronchial reactivity of allergic guinea-pigs. Am J Respir Crit Care Med 1994; 149: 1167-1174.
7. Kips JC, Cuvelier CA, Pauwels RA. Effect of acute and chronic antigen inhalation on airway morphology and responsiveness in actively sensitized rats. Am Rev Respir Dis 1992; 145: 1306-1310.

8. Metzger WJ, Zavala D, Richerson HB, et al. Local allergen challenge and bronchoalveolar lavage of allergic asthmatic lungs: description of the model and local airway inflammation. Am Rev Respir Dis 1987; 135: 433-440.

9. Chanez P, Bousquet J, Couret I, et al. Increased numbers of hypodense alveolar macrophages in patients with bronchial asthma. Am Rev Respir Dis 1991; 144: 923-930.

10. Sklar LA, McNeil VM, Jesaitis AJ, Pailter RG, Cochrane CG. A continuous spectroscopic analysis of the kinetics of elastase secretion by neutrophils. $J$ Biol Chem 1982; 257: 5471-5475.

11. Dunn CJ, Elliot GA, Oosteveen JA, Richards IM. Development of a prolonged eosinophil-rich inflammatory leukocyte infiltration in the guinea-pig asthmatic response to ovalbumin inhalation. Am Rev Respir Dis 1988; 137: 541-547.

12. Gleich GJ, Adolphson CR. Eosinophils. In: Crystal RG, West JB, eds. The Lung. Raven Press Ltd, 1991; pp. 581590.

13. Calhoun WJ, Kelly J. Cytokines in the respiratory tract. In: Chung KF, Barnes PJ, eds. Pharmacology of the Respiratory Tract. New York, Marcel Dekker Inc., 1993; pp. 253-288.

14. Gulbenkian AR, Fernandez X, Kreutner W, et al. Anaphylactic challenge causes eosinophil accumulation in bronchoalveolar lavage fluid of guinea-pigs: modulation by betamethasone, phenidone, indomethacin, WEB 2086 and a novel antiallergy agent SCH 37224. Am Rev Respir Dis 1990; 142: 680-685.

15. Venge P. Eosinophil-derived proinflammatory mediators. In: Jolles G, Karlsson J-A, Taylor J, eds. Tlymphocyte and Inflammatory Cell Research in Asthma. New York, Academic Press, 1993; pp. 133-149.

16. Frigas E, Motojima S, Gleich GJ. The eosinophilic injury to the mucosa of the airways in the pathogenesis of bronchial asthma. Eur Respir J 1991; 13: 123S-135S.

17. Beasley R, Roche RW, Roberts JA, Holgate ST. Cellular events in the bronchi in mild asthma and after bronchial provocation. Am Rev Respir Dis 1989; 139: 806-817.

18. Diaz P, Gonzalez MC, Galleguillos FR, et al. Leukocytes and mediators in bronchoalveolar lavage during allergeninduced late-phase asthmatic reactions. Am Rev Respir Dis 1989; 139: 1383-1389.

19. Metzger WJ, Richerson HB, Worden K, Monick M, Hunninghake GW. Bronchoalveolar lavage of allergic asthmatic patients following allergen bronchoprovocation. Chest 1986; 89: 477-483.

20. Sedgwick JB, Calhoun WJ, Gleich GJ, et al. Immediate and late airway response of allergic rhinitis patients to segmental antigen challenge: characterization of eosinophil and mast cell mediators. Am Rev Respir Dis 1991; 144: 1274-1281.

21. Laitinen LA, Heino M, Laitinen A, Kava T, Haahtela T. Damage of the airway epithelium and bronchial reactivity in patients with asthma. Am Rev Respir Dis 1985; 131: 599-606.

22. Wardlaw AJ, Dunnette S, Gleich GJ, Collins JV, Kay AB. Eosinophils and mast cells in bronchoalveolar lavage in subjects with mild asthma: relationship to bronchial hyperreactivity. Am Rev Respir Dis 1988; 137: 62-69. 
23. Azzawi M, Bradley B, Jeffery PK, et al. Identification of activated T-lymphocytes and eosinophils in bronchial biopsies in stable atopic asthma. Am Rev Respir Dis 1990; 142: 1407-1413.

24. Bousquet J, Chanez P, Lacoste JY, et al. Eosinophilic inflammation in asthma. $N$ Engl J Med 1990; 323: 1033 1039.

25. Bousquet J, Chanez P, Lacoste JY, et al. Indirect evidence of bronchial inflammation assessed by titration of inflammatory mediators in BAL fluid of patients with asthma. J Allergy Clin Immunol 1991; 88: 649-660.

26. Filley WV, Holley KE, Kemphart GM, Gleich GJ. Identification by immunofluoresence of eosinophil granule MBP in lung tissue of patients with bronchial asthma. Lancet 1982; ii: 11-16.

27. Minoguchi K, Adachi M, Kobayashi T, Takahashi T. The mechanism of airway hyperresponsiveness following the immediate anaphylactic response in albuminsensitized guinea-pigs. J Lipid Mediators 1992; 5: 169-172.

28. Turner NC, Dollery CT. Release of arachadonic acid metabolites and histamine from sensitized guinea-pig lung following antigen challenge. Br J Pharmacol 1988; 93: 751-758.

29. Mazzoni I, Morley J, Page CP, Sanjar S. Induction of airway hyperreactivity by platelet-activating factor in the guinea-pig. J Physiol 1985; 365: 107P.

30. Takehana Y, Hamano S, Kikuchi S, Komatsu H, Okegawa $\mathrm{T}$, Ikeda S. Inhibitory action of OKY-046HCl a specific $\mathrm{TxA}_{2}$ synthetase inhibitor on PAF-induced airway hyperresponsiveness of guinea-pigs. Jpn J Pharmacol 1990; 52: 621-630.

31. Giembycz MA, Kroegal C, Barnes PJ. Platelet-activating factor stimulates cyclo-oxygenase activity in guineapig eosinophils: concerted biosynthesis of thromboxane $\mathrm{A}_{2}$ and E-series prostaglandins. J Immunol 1990; 144: 3489 3497.

32. Ishida K, Thomson RJ, Schellenberg RR. Role of leukotrienes in airway hyperresponsiveness in guineapigs. Br J Pharmacol 1993; 108: 700-704.

33. Flavahan NA, Slifman NR, Gleich GJ, Vanhoutte PM. Human eosinophil major basic protein causes hyperreactivity of respiratory smooth muscle: role of the epithelium. Am Rev Respir Dis 1988; 138: 685-688.

34. Abramson SL, Malech HL, Gallin JI. Ncutrophils. In: Crystal RG, West JB, eds. The Lung. Raven Press Ltd., 1991; pp. 553-579.

35. Hutson PA, Church MK, Clay TP, Miller P, Holgate ST. Early- and late-phase bronchoconstriction after allergen challenge of nonanaesthetized guinea-pigs: the association of disordered airway physiology to leukocyte infiltration. Am Rev Respir Dis 1988; 137: 548-557.

36. Boichot E, Lagente V, Carre C, Waltmann P, MenciaHuerta JM, Braquet P. Bronchial hyperresponsiveness and cellular infiltration in the lung of guinea-pigs sensitized and challenged by aerosol. Clin Exp Allergy 1991; 21: 67-76.

37. Walls AF, Rhee YK, Gould DJ, et al. Inflammatory mediators and cellular infiltration of the lungs in a guineapig model of the late asthmatic reaction. Lung 1991; 169: 227240.

38. Smith HR, Larsen GL, Cherniak RM, et al. Inflammatory cells and eicosanoid mediators in subjects with late asthmatic responses and increases in airway responsiveness. $J$ Allergy Clin Immunol 1992; 89: 1076-1084.

39. Tarayre JP, Aliaga M, Barbara M, Tisseyre N, Vieu S, Tisne-Versailles J. Model of bronchial hyperreactivity after active anaphylactic shock in conscious guineapigs. $J$ Pharmacol Methods 1990; 23: 13-19.

40. Coyle AJ, Unwin SC, Page CP, Touvay C, Villain B, Braquet P. The effect of the selective PAF antagonist BN 52021 on PAF- and antigen-induced bronchial hyperreactivity and eosinophil accumulation. Eur J Pharmacol 1988; 148: $51-58$.

41. Poston RH, Chanez P, Lacoste JY, Litchfield T, Lee TH, Bousquet J. Immunohistochemical characterization of the cellular infiltration in asthmatic bronchi. Am Rev Respir Dis 1992; 145: 918-921.

42. Frew AJ, Moqbel R, Azzawi M, et al. T-lymphocytes and eosinophils in allergen-induced late-phase asthmatic reactions in the guinea-pig. Am Rev Respir Dis 1990; 141: 407-413.

43. Lapae Silva JR, Bachelet C-M, et al. Immunopathologic alterations in the bronchi of immunized guinea-pigs. Am J Respir Cell Mol Biol 1993; 9: 44-53. 